Abbreviated Key Title: Sch J Med Case Rep

ISSN 2347-9507 (Print) | ISSN 2347-6559 (Online)

Journal homepage: https://saspublishers.com

\title{
Immune Hydrops Fetalis: A Case Report
}

\author{
Bahaaedin A. Elkhader ${ }^{1 *}$
}

${ }^{1}$ Department of Radiological Sciences, College of Applied Medical Sciences, Taif University, Taif 21944, Saudi Arabia

DOI: $10.36347 /$ simcr.2021.v09i04.012

| Received: 11.03.2021 | Accepted: 17.04.2021 | Published: 19.04.2021

*Corresponding author: Bahaaedin A. Elkhader

\section{Abstract}

Hydrops fetalis is known as fluid accumulation in more than one location in the fetus. It can be classified into two types: immune or nonimmune. The second type is more common, due to improve in primary health care occurrence and mortality of the first one has reduced. A 30 years woman from the village with 27 weeks pregnancy, her blood group B negative. Sonography showed generalized body edema which indicated immune hydrops fetalis; which is considering rare nowadays. She had put under observation for further management.

Keywords: Immune hydrops fetalis, Ascites, Edema, antenatal care.

Copyright $(\mathcal{C}) 2021$ The Author(s): This is an open-access article distributed under the terms of the Creative Commons Attribution 4.0 International License (CC BY-NC 4.0) which permits unrestricted use, distribution, and reproduction in any medium for non-commercial use provided the original author and source are credited.

\section{INTRODUCTION}

Hydrops fetalis also known as fetal hydrops is state in which exaggerated fluids are gathering in multiple parts of the body of fetus [1].

According etiology of the disease, it sorts in two groups. Group one which became rare nowadays because of good health care which it related to $\mathrm{Rh}$ alloimmunization and other group caused by other conditions. General they are labeled as immune and nonimmune hydrops fetalis [2]. Cardiac insufficiency is due to vascular disorders in fetus and not associate with fetal hydrops [3]. As general occurrence of fetal hydrops among pregnancies women stated in the previous works is low [4].

\section{Case Report}

A 30 years old multipara woman, G3P1011, she is from a village far from the city center. She suffers from overwhelming economic conditions with a lack of education. Her husband died five months ago. There was no clear medical history for any chronic diseases. According her circumstance, she did not obtain prefect pre-birth care in the beginning of pregnancy. She referred to maternity hospital complains of labor sign (cramps and vaginal discharge). She had B negative blood group. Ultrasonography reported that a single viable fetus with GA- 27 weeks, 0 days, and, also illustrated multiple fluids collection in fetus body. Skin edema, hydrothorax, multiple ascites, thickened placenta and scrotal edema (Figures 1-4) were main ultrasound finding. The patient put under obstetrician and neonatologist observation, but the prognosis is very poor.

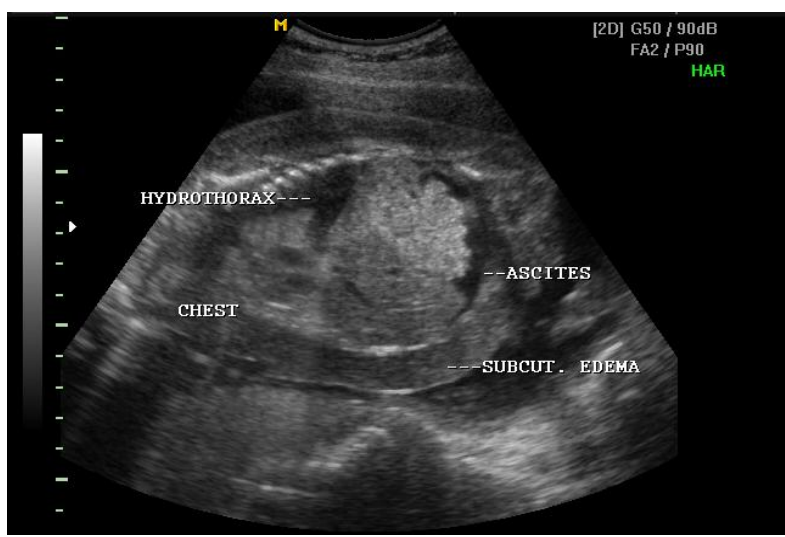

Fig-1: Ultrasound showed hydrothorax, skin edema and ascites

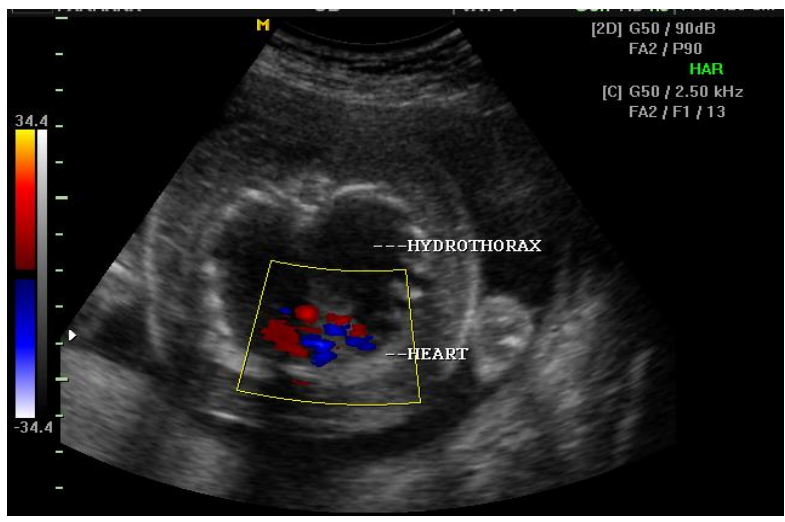

Fig-2: Doppler sonography showed hydrothorax around the fetal heart 


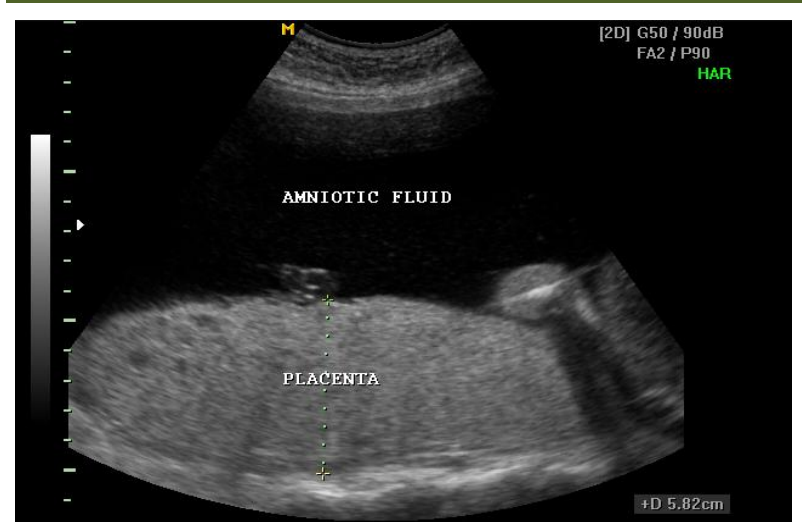

Fig-3: U/S showed enlarged placenta

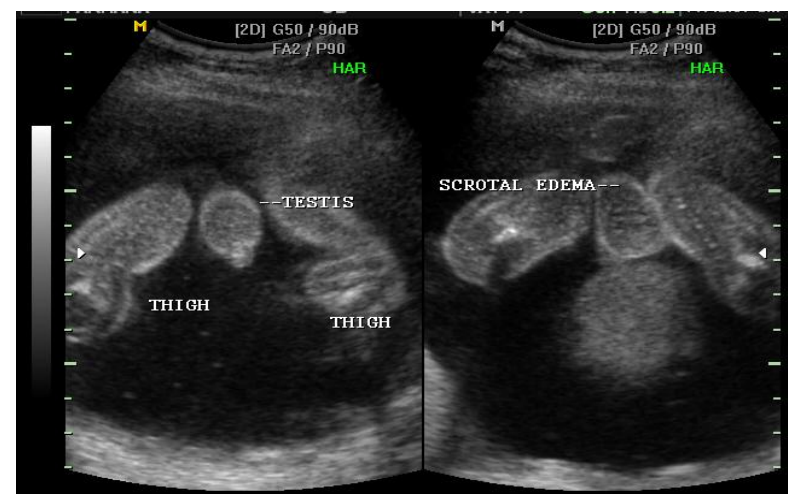

Fig-4: U/S showed scrotal edema

\section{DISCUSSION}

Hydrops fetalis is the fluid gathering in two or more body sections it can found in chest, abdomen, pleural cavities and skin, [5]. The rate of cases is about 1 in 2,500 to 1 in 3,500 neonates [6]. The disease has two types depending on its etiology comprise of an immune type and a nonimmune one [7].

A fetal hydrops nonimmune type has various reasons. Despite the belief prevailing in the past that the cause is unknown. Current literature review displays that an origin can be recognized before birth in $65 \%$ of cases and up to $85 \%$ after childbirth [8].

The discovery of treatment of RhD isoimmunization lead to decrease the rate of prevalence and death of immune hydrops fetalis [9-11].

In this case the history of patient tends to suppose a diagnosis of immune hydrops fetalis which considering a rare case. This case caught attention to the need of primary health care in the countryside to avoid any future abnormalities.

\section{Conclusion}

Although a vaccine is available to treat $\mathrm{RhD}$ isoimmunization, some mothers may not be able to get it in time. Increasing awareness and health education and providing excellent primary care in rural areas would reduce the mortality rate among neonates.

\section{REFERENCES}

1. Kontomanolis EN, Fasoulakis Z. Hydrops Fetalis and the Parvovirus B-19. Curr Pediatr Rev. 2018;14(4):239-252.

2. Singla S, Kumar S, Roy KK, Sharma JB, Kachhawa G. Severe hydrops in the infant of a Rhesus D-positive mother due to anti-c antibodies diagnosed antenatally: a case report. J Med Case Rep. 2010 Feb 18;4:57.

3. Thammavong $\mathrm{K}$, Luewan $\mathrm{S}$, Wanapirak $\mathrm{C}$, Tongsong T. Ultrasound Features of Fetal Anemia Lessons From Hemoglobin Bart Disease. J Ultrasound Med. 2021 Apr;40(4):659-674.

4. Hutchison AA, Drew JH, Yu VY, Williams ML, Fortune DW, Beischer NA. Nonimmunologic hydrops fetalis: a review of 61 cases. Obstetrics and gynecology. 1982 Mar 1;59(3):347-52.

5. Hamdan AH. Hydrops fetalis: eMedicine Pediatrics: cardiac disease and critical care medicine. Available at: www.emedicine.medscape.com. [Accessed 11 February 2010]

6. Bijma HH, Schoonderwaldt EM, van der Heide A, Wildschut HI, van der Maas PJ, Wladimiroff JW. Ultrasound diagnosis of fetal anomalies: an analysis of perinatal management of 318 consecutive pregnancies in a multidisciplinary setting. Prenatal diagnosis. 2004 Nov;24(11):8905.

7. Randenberg AL. Nonimmune hydrops fetalis part II: does etiology influence mortality? Neonatal Netw 2010;29(6):367-380. DOI: 10.1891/07300832.29.6.367.

8. Gilby DM, Mee JB, Kamlin CO, Kornman LH, Davis PG, Manley BJ. Outcomes following antenatal identification of hydrops fetalis: a singlecentre experience from 2001 to 2012. Archives of Disease in Childhood-Fetal and Neonatal Edition. 2019 May 1;104(3):F253-8.

9. Graves GR, Baskett TF. Nonimmune hydrops fetalis: Antenatal diagnosis and management. American Journal of Obstetrics and Gynecology. 1984; 148:563-565.

10. Bellini C, Hennekam RC, Fulcheri E, Rutigliani M, Morcaldi G, Boccardo F, Bonioli E. Etiology of nonimmune hydrops fetalis: a systematic review. American journal of medical genetics Part A. 2009 May;149(5):844-51.

11. Steurer MA, Peyvandi S, Baer RJ, MacKenzie T, Li BC, Norton ME, Jelliffe-Pawlowski LL, MoonGrady AJ. Epidemiology of Live Born Infants with Nonimmune Hydrops Fetalis-Insights from a Population-Based Dataset. The Journal of pediatrics. 2017 Aug 1;187:182-8.

12. Pasman SA, Meerman RH, Vandenbussche FP, Oepkes D. Hypoalbuminemia: A cause of fetal hydrops?. American journal of obstetrics and gynecology. 2006 Apr 1;194(4):972-5. 